УДК 338.43: 631.1.016

DOI: 10.24144/2078 -1431.2020.1(24).132-140

Леся Газуда,

доктор економічних наук, професор, професор кафедри економіки підприємства

Вікторія Герцег,

аспірантка кафедри економіки підприємства ДВНЗ «Ужгородський національний університет»

\title{
СФЕРА АГРАРНОГО ГОСПОДАРЮВАННЯ ЯК КЛЮЧОВИЙ ФАКТОР РОЗВИТКУ СІЛЬСЬКИХ ТЕРИТОРІЙ
}

Актуальність теми зумовлена тим, що сфера аграрного господарювання займає особливе місце у забезпеченні розвитку сільських територій, поряд із такими видали економічної діяльності на селі, як промисловість, торгівля, туризм та багато інших. Досліджувана галузь виробляе продукцію для задоволення потреб суспільства, відіграючи вагому роль у забезпеченні інфраструктурного розвитку сільських територій. Стан соиіально-економічного розвитку сільських територій Закарпатської області є індикатором рівня добробуту населення регіону та потребуе задіяння інтегрованого галузево-територіального niдxодy.

Дослідження засвідчило, щзо в забезпеченні розвитку сільських територій Закарпатської області вагому роль відіграе ефективне функціонування аграрних підприемств, зокрема господарств населення, тобто сфери аграрного господарювання в изілму. Незважаючи на те, щзо дослідженням підтверджено позитивну динаміку з окремих позицій у напрямі зростання, в ціілому стан сільського господарства області можна вважати задовільним. 3 огляду на відмічене, сфера аграрного господарювання потребує дієвої державної підтримки, передусім через регіональні програми соціального, економічного й екологічного регулювання з урахуваннял пріоритетних цілей $і$ завдань стосовно розвитку сільської місиевості.

Ключові слова: сільське господарство, валова продукція, рослинництво, тваринництво, динаміка виробництва, сільськогосподарські угіддя.

The purpose of the article. Today, rural areas are a very complex subject for research and management. The urgency of the topic is due to the fact that agriculture occupies a special place in ensuring the development of rural areas, along with such types of economic activity in the countryside as industry, commerce, tourism and many others. This industry produces products to meet the needs of society and plays an important role in ensuring the infrastructural development of rural areas. The purpose of the article is to investigate the problems of agricultural development in the Transcarpathian region as one of the key components of rural development. The state of socio-economic development of rural areas of the Transcarpathian region is an indicator of the level of well-being of the region and requires an integrated sectoral-territorial approach. 
Research methodology. Transcarpathian statistics for the years 2010-2019 were used for the study. The number of economic entities in this field, the state of agricultural land, the dynamics of agricultural production, the production of the main types of agricultural products were analyzed: crop production, livestock production and $d y$ namics of agricultural product indices 2011-2018.

Results. The main problems that arise in agriculture include: dependence on natural and climatic conditions, the need to improve state regulation in this area, lack of support and incentives for small businesses in the agricultural sector, outdated logistics, inefficient marketing policies and others. Consideration should also be given to the environmental safety of the products produced, to reducing the negative impact on the environment, to improving soil fertility and to ensuring the sustainable development of agriculture and rural areas. Increased agricultural production and the efficient functioning of agriculture are driving the development of rural areas in the region.

Practical meaning. The practical significance is that certain results can be used in practical activities to make management policy decisions in the field of rural area development.

Novelty. Agriculture needs effective state support, which must be built on the scientific base and experience of developed countries. The aforementioned research needs areas of social infrastructure that directly influence the formation of socio-economic potential of the Ukrainian village.

Keywords: agriculture, gross production, crop production, animal husbandry, dynamics of production, agricultural lands.

Постановка проблеми. Сфера аграрного господарювання є первинною ланкою агропромислового комплексу (АПК), яка відіграє важливу роль у забезпеченні соціально-економічного розвитку сільських територій та покращенні добробуту та життєвого рівня населення.

Аналіз останніх досліджень і публікацій. Дослідженням проблем розвитку сільських територій присвячені праці відомих науковців: М. Лендєла, М. Орлатого, Б. Панасюка, С. Писаренка, В. Юрчишина, І. Прокопа, П. Саблука, Я. Шевчука та інших дослідників-економістів аграрного спрямування.

Метою статті є дослідження проблем аграрного господарювання в Закарпатській області як одного 3 ключових компонентів розвитку сільських територій.

Виклад основного матеріалу дослідження. Сфера аграрного господарювання - галузь матеріального виробництва, що займається вирощуванням культурних рослин та розведенням домашніх тварин для забезпечення населення продуктами харчування, а промисловості - сировиною. Воно включає дві взаємопов'язані великі галузі - рослинництво (його ще називають землеробством) і тваринництво [13].

Відродження сільських територій, на думку Б. Панасюка, є мождивим за умови виведення господарства із скрутного становища, відновлення його виробничої бази, кооперації сільськогосподарського виробництва 3 переробною промисловістю і торгівлею, розвитку агропідприємств [11, c. 211]. 
Нині актуальності набуває проведення комплексного аналітичного дослідження стану аграрної сфери та виявлення основних причин їі погіршення на регіональному рівні, зокрема в Закарпатській області.

Аграрне господарювання займає провідне місце в економіці області, саме у цій сфері зосереджено 3463 суб'єкти господарювання, серед них 1170 підприємств та 2293 фізичних осіб-підприємців [5]. У структурі населення регіону переважає сільське населення - 62,9 \% за статистичними даними станом на 2019 р. Однак сільськогосподарське виробництво у Закарпатській області має певні особливості: по-перше, регіон є малоземельним; по-друге, його грунти - невисокої якості, переважно із значною генетичною кислотністю, що потребують обов' язкової хімічної меліорації; по-третє, область характеризується вертикальною зональністю (виділяють такі зони: низинна, передгірна та гірська, яка займає дві третини території області). Для низинної зони характерні такі галузі сільськогосподарського виробництва: зерновиробництво, картоплярство, виноградарство, кормовиробництво, молочне скотарство та свинарство. Для передгірної зони: картоплярство, садівництво, вирощування винограду та кормових і зернофуражних культур. У гірській зоні - скотарство і вирощування картоплі.

Сільськогосподарські угіддя в Закарпатській області становдять 451 тис. га, 3 них 200 тис. га - рілля, 94 тис. га - сіножаті, 129 тис. га - пасовища, 27 тис. га - багаторічні насадження (згідно з даними Держгеокадастру станом на 01.10.2019 р.) [7].

Динаміку виробництва сільськогосподарської продукції Закарпатської області в розрізі рослинництва і тваринництва подано у табл. 1.

Таблиця 1

Продукція сільського господарства Закарпатської області за період 2010-2019 pp. [14, 5].

(у постійних цінах 2010 року; млн. грн)

\begin{tabular}{|l|c|c|c|c|c|c|c|c|}
\hline \multicolumn{7}{|c|}{ Господарства усіх категорій } \\
\hline & $\mathbf{2 0 1 0}$ & $\mathbf{2 0 1 1}$ & $\mathbf{2 0 1 2}$ & $\mathbf{2 0 1 5}$ & $\mathbf{2 0 1 6}$ & $\mathbf{2 0 1 7}$ & $\mathbf{2 0 1 8}$ & $\mathbf{2 0 1 9}$ \\
\hline $\begin{array}{l}\text { Продукція сільського } \\
\text { господарства, в тому } \\
\text { числі: }\end{array}$ & 3838,3 & 4044,8 & 4207,3 & 4095,9 & 3929,2 & 4021,4 & 4301,2 & 4263,9 \\
\hline $\begin{array}{l}\text { продукція рослинни- } \\
\text { цтва }\end{array}$ & 1771,2 & 1968,2 & 2128,6 & 2099,3 & 2122,3 & 2089,0 & 2198,8 & 2145,7 \\
\hline $\begin{array}{l}\text { продукція тваринни- } \\
\text { цтва }\end{array}$ & 2067,1 & 2076,6 & 2184,3 & 1996,6 & 1806,9 & 1932,4 & 2102,4 & 2118,2 \\
\hline
\end{tabular}

Валова продукція сільського господарства (табл. 1) в 2019 р. становила 4263,9 млн. грн. (у порівняльних цінах 2010 р.), що становить 1,6 \% валової продукції сільського господарства України за відповідним показником, та зайняла 24 місце серед регіонів країни. У 2010 р. зазначений показник становив 3838,3 млн. грн, тоді як у 2019 р. 4263,9 млн. грн, тобто зріс на $11 \%$. Стосовно галузевої структури виробництва, то продукція рослинництва 
у 2010 р. становила 1771,2 млн. грн, тоді як у 2019 р. 2145,7 млн. грн, таке зростання становить 21 \%. Відповідно продукція тваринництва у 2010 р. становила 2067,1 млн. грн, а у 2019 р. 2118,2 млн. грн, тобто зросла на 2 \%. Таким чином, можна відмітити, що загальна тенденція виробництва сільськогосподарської продукції має позитивну динаміку, хоч порівняно з останніми роками і незначну (рис. 1).

Рослинництво як невід'ємна складова частина агропромислового комплексу відіграє важливу роль у формуванні валового регіонального продукту. Рівень життя людей регіону безпосередньо залежить від вирощування сільськогосподарських культур для особистого споживання та як кормової бази для тварин.

У рослинництві Закарпатської області серед виробництва основних сільськогосподарських культур переважають: картопля - 4946,8 тис. ц, зернові та зернобобові - 3916,5 тис. ц, овочеві культури - 2709,9 тис. ц, соняшник $-80,3$ тис. ц. [3]

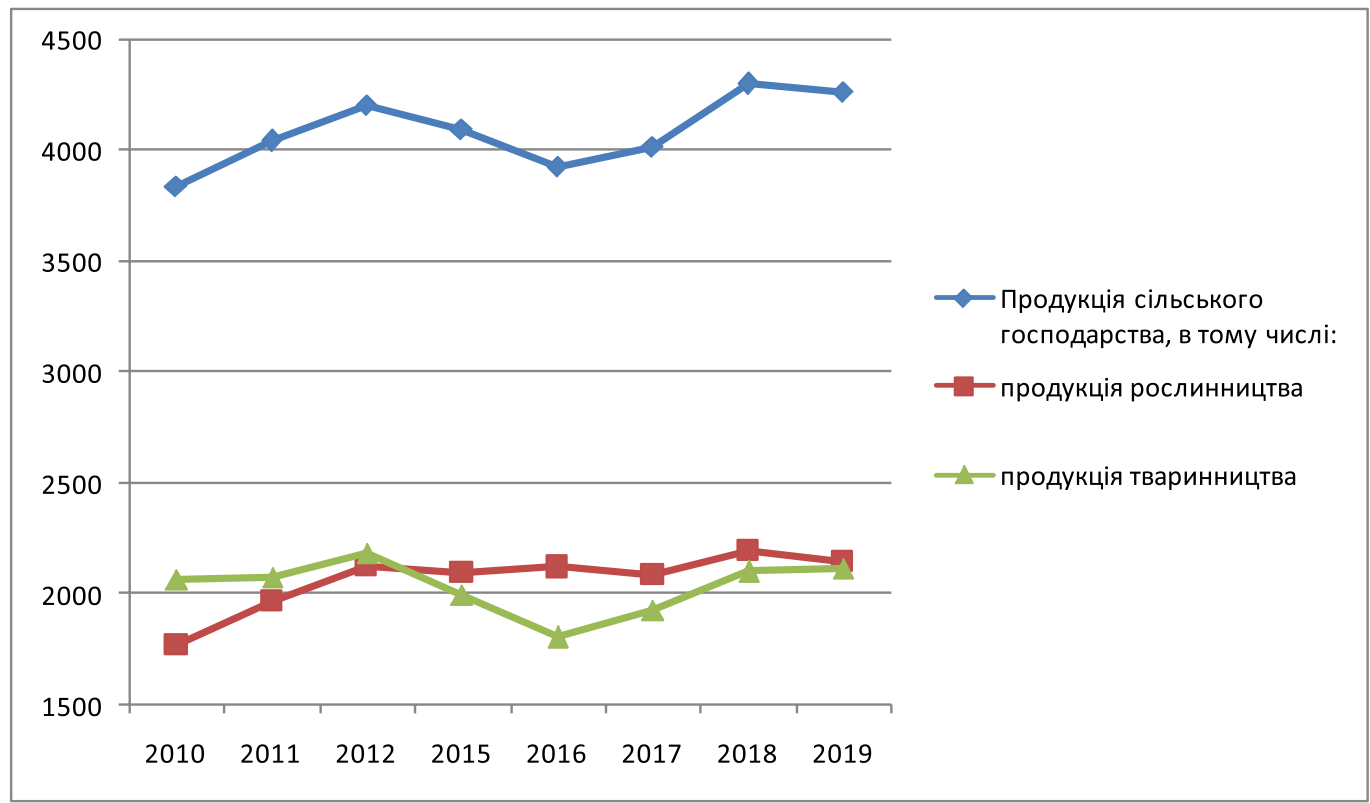

Рис. 1. Динаміка виробництва сіхьськогосподарської продукції Закарпатської обл. ${ }^{*}$

*Сформовано за даними табл. 1.

У галузі тваринництва основними продуктами виробництва є: м'ясо 85,9 тис. т, молоко - 350 тис. т, яйця - 410,7 тис. т (станом на 1 дистопада 2019 р.)[1]. Тваринництво області поділяється на розведення великої рогатої худоби, у тому числі й корів, свиней, овець, кіз та свійської птиці. Воно забезпечує населення як продуктами харчування (молоко, м'ясо, масло, сир, сметана, інші продукти молоко- та м'ясопереробки), так і є джерелом сировини для легкої (вовна, шкури, овчини), харчової та фармацевтичної промисловості. 
Тваринництво у 2014-2020 рр. (кількість сільськогосподарських тварин на 1 січня 2020 р., тис. голів) представлено у табл. 2. Якщо порівняти ці показники у 2020 р. $з$ показниками у 2014 р., то простежується така динаміка: кількість великої рогатої худоби зменшилась. Так, у 2014 р. було 144,3 тис. голів, у 2020 р. - 123,4 тис. голів, у тому числі корів з 101,2 тис. голів зменшилося до 87,7 тис. голів відповідно. Кількість свиней також зменшилася з 287,8 тис. голів у 2014 р. до 248,8 тис. голів у 2020 р. Кількість овець та кіз також зменшилася за аналізований період з 166 тис. голів до 150,1 тис. голів. Позитивним варто вважати збільшення кількості свійських птахів - 3 3310,7 тис. голів у 2014 році до 3551,7 тис. голів у 2020 році.

Таблиця 2

\section{Тенденція розвитку тваринництва в Закарпатській області за період 2014-2020 рр. [9] \\ (muc. 20лis)}

\begin{tabular}{|l|c|c|c|c|c|c|c|}
\hline \multicolumn{1}{|c|}{ Показники } & $\mathbf{2 0 1 4}$ & $\mathbf{2 0 1 5}$ & $\mathbf{2 0 1 6}$ & $\mathbf{2 0 1 7}$ & $\mathbf{2 0 1 8}$ & $\mathbf{2 0 1 9}$ & $\mathbf{2 0 2 0}$ \\
\hline $\begin{array}{l}\text { Велика рогата худоба, } \\
\text { усього }\end{array}$ & 144,3 & 132,0 & 127,7 & 122,2 & 120,9 & 122,9 & 123,4 \\
\hline у т.ч. корови & 101,2 & 93,7 & 91,1 & 87,6 & 86,1 & 87,4 & 87,7 \\
\hline свині & 287,8 & 280,1 & 274,9 & 262,6 & 229,8 & 242,7 & 248,8 \\
\hline вівці та кози & 166,0 & 150,1 & 145,4 & 141,6 & 141,1 & 153,7 & 150,1 \\
\hline птиця свійська & 3310,7 & 3270,1 & 3340,4 & 3119,0 & 3047,4 & 3240,7 & 3551,7 \\
\hline
\end{tabular}

Дослідження підтверджує, що в розрізі районів області з виробництва продукції тваринництва, зокрема виробництва м'яса (2018р.), першість належить Мукачівському, Тячівському та Хустському районам; у виробництві модока попереду Тячівський, Берегівський, Виноградівський райони; у виробництві яець - Виноградівський район [2].

Індекс сільськогосподарської продукції відображає рівень змін фізичного обсягу виробництва продукції сільського господарства, виробленого за періоди, виокремлені для порівняння [8]. Індекси сільськогосподарської продукції за період 2011-2018 рр. наведено у табл. 3.

За 2018 р. індекс обсягу виробництва валової продукції сільського господарства всіма категоріями господарств у регіоні становив 107,0 \% до рівня попереднього року, порівняно з 2011 р. - збільшився на 1,6 \%, фактично за рахунок продукції тваринництва, індекс якої у 2018 р. становив 108,8 \%, що на 8,3\% більше, ніж у 2011 р. Індекс продукції рослинництва, навпаки, знизився на 5,8 \% і становив у 2018 р. 105,3 \%. Дослідження підтверджуе, що індекс обсягу виробництва валової продукції сільського господарства підприємствами у 2018 р. становив 112,8 \%, що на 29,1 \% менше $з$ порівнюваним роком. 
Таблиця 3

Індекси сільськогосподарської продукції у Закарпатській області за період 2011-2018 рр. [8]

( \% до попереднього року)

\begin{tabular}{|c|c|c|c|c|c|c|c|c|}
\hline & \multirow{2}{*}{ Продукція } & \multirow{2}{*}{2011} & \multirow{2}{*}{2014} & \multirow{2}{*}{2015} & \multirow{2}{*}{2016} & \multirow{2}{*}{2017} & \multirow{2}{*}{2018} & Абс. зміна \\
\hline & & & & & & & & 2018 да о 2011 \\
\hline \multirow{3}{*}{ 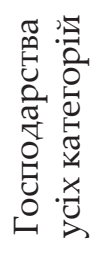 } & $\begin{array}{l}\text { Сільського госпо- } \\
\text { дарства }\end{array}$ & 105,4 & 99,9 & 95,1 & 96,8 & 101,4 & 107,0 & 1,6 \\
\hline & Рослинництва & 111,1 & 103,3 & 95,4 & 101,8 & 97,7 & 105,3 & $-5,8$ \\
\hline & Тваринництва & 100,5 & 96,5 & 94,7 & 91,5 & 105,8 & 108,8 & 8,3 \\
\hline \multirow{3}{*}{ 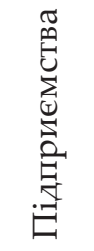 } & $\begin{array}{l}\text { Сільського госпо- } \\
\text { дарства }\end{array}$ & 141,9 & 120,6 & 115,0 & 113,7 & 93,6 & 112,8 & $-29,1$ \\
\hline & Рослинництва & 167,5 & 133,5 & 125,0 & 119,0 & 95,0 & 120,4 & $-47,1$ \\
\hline & Тваринництва & 107,8 & 95,8 & 88,0 & 93,7 & 86,8 & 72,1 & $-35,7$ \\
\hline \multirow{3}{*}{ 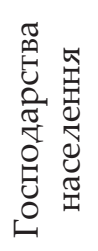 } & $\begin{array}{l}\text { Сільського госпо- } \\
\text { дарства }\end{array}$ & 103,9 & 98,7 & 93,7 & 95,4 & 102,2 & 106,4 & 2,5 \\
\hline & Рослинництва & 108,4 & 101,1 & 92,5 & 99,5 & 98,2 & 102,9 & $-5,5$ \\
\hline & Тваринництва & 100,2 & 96,6 & 94,9 & 91,4 & 106,4 & 109,8 & 9,6 \\
\hline
\end{tabular}

Тенденція до зниження показників простежуеться як щодо продукції тваринництва - на 35,7 \%, так і продукції рослинництва - на 47,1 \%. Водночас індекс продукції сільського господарства у 2018 р. становив 106,4 \%, а у 2011 р. 103,9 \%, тобто збільшився на 2,5 \%, що пояснюється підвищенням індексу виробництва продукції тваринництва на 9,6 \%, оскільки у 2011 р. він становив 100,2 \%, а у 2018 р. - 109,8 \%. Індекс продукції рослинництва у господарствах населення зменшився на 5,5 \%, порівняно з 2011 р. і у 2018 р. становив 102,9 \%.

Таким чином, збільшення виробництва сільськогосподарської продукції відбувається за рахунок господарств населення, які здатні задовольняти не лише особисті, а й суспільні інтереси у сільському господарстві. У сучасних умовах вони є реальними конкурентами аграрних підприємств у виробництві сільськогосподарської продукції.

У наукових джерелах виокремлюють різновиди господарств населення, які можуть бути індивідуадьними, особистими, підсобницькими та фермерськими. В. Збарський та М. Канінський у статті «Особисті селянські господарства: місце і роль у продовольчому забезпеченні країни», дають таке визначення особистих селянських господарств - особлива, заснована на приватній власності форма господарювання селян (як фізичних осіб), що здійснюють виробництво, переробку, споживання сільськогосподарської продукції та реалізації ії надлишків [6]. В зазначеному визначенні 
мова йде про надлишки, однак дослідження підтверджують, що серед виробників сільськогосподарської продукції важдива роль належить саме господарствам населення.

Дослідження засвідчило, що для забезпечення розвитку сільських територій Закарпатської області вагому роль відіграє ефективне функціонування аграрних підприємств, зокрема господарств населення, тобто сфери аграрного господарювання в цілому. Незважаючи на те, що дослідженням підтверджено позитивну динаміку з окремих позицій у напрямі зростання, в цілому стан сільського господарства області можна вважати задовільним. 3 огляду на відмічене сфера аграрного господарювання потребує дієвої державної підтримки, передусім через регіональні програми соціального, економічного й екологічного регулювання з врахуванням пріоритетних цілей і завдань стосовно розвитку сільської місцевості.

Поряд 3 цим актуалізації набуває раціональне використання і охорона сільськогосподарських земель відповідно до земельного законодавства, покращення якісного стану грунтів, вдосконалення сервісного обслуговування населення, збільшення конкурентоспроможності продукції, упровадження ефективної маркетингової політики, вирішення проблеми технологічного відставання та забезпечення їх малогабаритною технікою й інвентарем, для зменшення затрат ручної праці. Регіон має всі ресурси для розвитку галузі, проблема виникає в ефективному їх використанні.

\section{Висновки і перспективи подальших досліджень.}

Отже, збільшення виробництва сільськогосподарської продукції та ефективне функціонування сфери аграрного господарювання спонукає до розвитку сільських територій регіону, адже сільське господарство є однією з ключових сфер матеріального виробництва на селі та забезпечення продоводьством сільського населення.

Практична значущість дослідження полягає в тому, що певні результати можуть бути використані у практичній діяльності для прийняття управлінських рішень у сфері розвитку територій сільської місцевості.

Вищезгаданого дослідження потребують галузі соціальної інфраструктури, які безпосередньо впливають на формування соціально-економічного потенціалу українського села.

\section{СПИСОК ВИКОРИСТАНИХ ДЖЕРЕ}

1. Виробництво основних видів продукції тваринництва у 2019 році. Статистична інформація URL: http://www.uz.ukrstat.gov.ua/statinfo/apk/2019/virob_prod_ tvar_2019.pdf. (дата звернення: 09.04.2020).

2. Виробництво продукції тваринництва у підприємствах по районах у 2018 році. Статистична інформація URL: http://www.uz.ukrstat.gov.ua/statinfo/apk/2018/ virob_prod_tvar_rajony_2018.pdf . (дата звернення: 09.04.2020).

3. Виробництво сільськогосподарських культур у 2019 році. Статистична інформація URL: http://www.uz.ukrstat.gov.ua/statinfo/apk/2019/vyrob_sh_cult_2019.pdf. (дата звернення: 08.04.2020).

4. Головне управління статистики у Закарпатській області. Статистична інформація URL: http://www.uz.ukrstat.gov.ua/statinfo/apk/index.html. (дата звернення: 13.04.2020). 
5. Економічна статистика. Економічна діяльність.Сільське, дісове та рибне господарство. URL: http://www.ukrstat.gov.ua/operativ/menu/menu_u/cg.htm. (дата звернення: 09.04.2020).

6. Збарський В.К., Канінський М.П. Особисті селянські господарства: місце і роль у продовольчому забезпеченні країни // АГРОІНКОМ, 2008. №1-2. С. 27-32.

7. Земельний довідник України 2020 - база даних про земельний фонд країни. URL: https://agropolit.com/spetsproekty/705-zemelniy-dovidnik-ukrayini--bazadanih-pro-zemelniy-fond-krayini (дата звернення: 10.04.2020).

8. Індекси сільськогосподарської продукції (1991-2018 роки). Статистична інформація. URL: http://www.uz.ukrstat.gov.ua/statinfo/apk/2019/index_apk_1991-2018. pdf (дата звернення: 13.04.2020).

9. Кількість сільськогосподарських тварин . Статистична інформація. URL: http:// www.ukrstat.gov.ua/operativ/operativ2020/sg/ksgt/arh_ksgt2020_u.html (дата звернення: 09.04.2020).

10. Мармуль Л.О. Методичні підходи до розвитку сільських територій на засадах децентралізації // Економіка АПК,2016 . №7. С. 80-86.

11. Панасюк Б.Я. Шлях до відродження села // Соціально-економічні проблеми розвитку українського села і сільських територій: матеріали сьомих річних зборів Всеукраїнського конгресу вчених економістів-аграрників. К., 2005. С. 211-217.

12. Проєкт Єдиної комплексної стратегії розвитку сільського господарства та сільських територій на 2015-2020 роки /Міністерство аграрної політики та продовольства України. URL: http://minagro.gov.ua/system/files. (дата звернення: 06.04.2020).

13. Сільське господарство. Вікіпедія: вільна енциклопедія. URL: https://uk.wikipedia. org/wiki/Сільське_господарство. (дата звернення: 10.04.2020).

14. Сільське господарство Закарпаття за 2010-2017 роки: статистичний збірник/ Державна служба статистики України. Головне управління статистики у Закарпатській області. Ужгород, 2018. 60 с.

15. Сільське, лісове та рибне господарство. Статистична інформація. URL: 9http:// www.ukrstat.gov.ua/operativ/operativ2017/sg/pro_sg/arch_pro_sg_p.htm (дата звернення: 08.04.2020).

16. Схема планування території Закарпатської області, розроблена авторським колективом АПМ-1 (начальник - В. Токар) спільно зі спеціалістами інженерно-планувального відділу (начальник - Муха В. Г.). Київ, 2011. С. 43. URL: https://carpathia. gov.ua/sites/default/files/imce/130517_731-i.pdf (дата звернення: 06.04.2020).

\section{REFERENCES}

1. Vyrobnytstvo osnownykh vydiv produktsiyi toarynnytstva u 2019 rotsi. Statystychna informatsiya [Production of basic livestock products in 2019. Statistical information]. Retrieved from http://www.uz.ukrstat.gov.ua/statinfo/apk/2019/virob_prod_tvar_2019.pdf. (accessed 9 April 2020). [in Ukrainian].

2. Vyrobnytstvo produktsiyi tvarynnytstva u pidpryyemstvakh po rayonakh u 2018 rotsi. Statystychna informatsiya [Production of livestock products in enterprises by districts in 2018. Statistical information.]. Retrieved from http://www.uz.ukrstat.gov.ua/statinfo/apk/2018/ virob_prod_tvar_rajony_2018.pdf (accessed 9 April 2020). [in Ukrainian].

3. Vyrobnytstvo silskohospodarskykh kultur u 2019 rotsi. Statystychna informatsiya [Crop production in 2019. Statistical information]. Retrieved from http://www.uz.ukrstat.gov.ua/ statinfo/apk/2019/vyrob_sh_cult_2019.pdf. (accessed 8 April 2020). [in Ukrainian].

4. Holovne upravlinnya statystyky u Zakarpatskiy oblasti. Statystychna informatsiya [Main Department of Statistics in the Transcarpathian region. Statistical information]. Retrieved from http://www.uz.ukrstat.gov.ua/statinfo/apk/index.html. (accessed 13 April 2020). [in Ukrainian]. 
5. Ekonomichna statystyka. Ekonomichna diyalnist. Silske, lisove ta rybne hospodarstvo [Economic statistics. Economic activities. Agricultural, forestry and fisheries]. Retrieved from http://www.ukrstat.gov.ua/operativ/menu/menu_u/cg.htm. (accessed 9 April 2020), [in Ukrainian].

6. Zbarskyy, V. K., \& Kaninskyy, M. P. (2008). Osobysti selyanski hospodarstva: mistse i rol u prodovolchomu zabezpechenni krayiny [Personal peasant farms: place and role in the country's food supply]. AHROINKOM [in Ukrainian].

7. Zemelnyy dovidnyk Ukrayiny 2020 - baza danykh pro zemelnyy fond krayiny [Land Directory of Ukraine 2020 - database on the land fund of the country]. Retrieved from https:// agropolit.com/spetsproekty/705-zemelniy-dovidnik-ukrayini--baza-danih-pro-zemelniy-fond-krayini (accessed 10 April 2020). [in Ukrainian].

8. Indeksy silskohospodarskoyi produktsiyi (1991-2018 roky). Statystychna informatsiya [Agricultural production indices (1991-2018). Statistical information]. Retrieved from http:// www.uz.ukrstat.gov.ua/statinfo/apk/2019/index_apk_1991-2018.pdf (accessed 13 April 2020). [in Ukrainian].

9. Kilkist silskohospodarskykh tvaryn. Statystychna informatsiya [Number of farm animals. Statistical information]. Retrieved from http://www.ukrstat.gov.ua/operativ/operativ2020/sg/ksgt/arh_ksgt2020_u.html 10. (accessed 9 April 2020). [in Ukrainian].

10. Marmul, L.O. (2016). Metodychni pidkhody do rozvytku sil's'kykh terytoriy na zasadakh detsentralizatsiyi [Methodical approaches to rural development on the basis of decentralization]. Ekonomika APK, 7 [in Ukrainian].

11. Panasyuk, B.YA. (2005). Shlyakh do vidrodzhennya sil. Sotsialno-ekonomichni problemy rozvytku ukrayinskoho selyshcha ta silskykh terytoriy (materialy svidomykh richkovykh sluzhbovtsiv Vseukrayins'koho konhresu v ekonomichnykh ekonomikakh-ahrarnykiv) [The way to the revival of villages. Socio-economic problems of development of Ukrainian settlement and rural territories]. Kyiv, Ukraina. [in Ukrainian].

12. Proekt Yedynoyi kompleksnoyi stratehiyi rozvytku sil's'koho hospodarstva ta sil's'kykh terytoriy na 2015-2020 roky (Ministerstvo ahrarnoyi polityky ta rozvytku Ukrayiny)[Draft Integrated Strategy for Development of Agriculture and Rural Territories for 2015-2020 ]. Retrieved from http://minagro.gov.ua/system/files. (accessed 6 April 2020). [in Ukrainian].

13. Silske hospodarstvo (Vikipediya: vilna entsyklopediya)[Agriculture (Wikipedia: The free encyclopedia)]. Retrieved from https://uk.wikipedia.org/wiki/Sil's'ke_horanstvo. (accessed 10 April 2020). [in Ukrainian].

14. Silske hospodarstvo Zakarpattya za 2010-2017 roky: statystychnyy zbirnyk. (2018) Derzhavnoyi sluzhby statystyky Ukrayiny. Holovne upravlinnya statystykoyu v Zakarpat.s'kiy oblasti [Transcarpathian agriculture for 2010-2017: statistical compilation of the State Statistics Service of Ukraine. Main Department of Statistics in the Transcarpathian region]. Uzhhorod [in Ukrainian].

15. Silske, lisove ta rybne hospodarstvo. Statystychna informatsiya [Agriculture, forestry and fisheries. Statistical information]. Retrieved from http://www.ukrstat.gov.ua/operativ/ operativ2017/sg/pro_sg/arch_pro_sg_p.htm (accessed 8 April 2020). [in Ukrainian].

16. Skhema planuvannya terytoriyi Zakarpatskoyi oblasti( rozroblena avtorskym kolektyvom APM-1 (nachalnyk - V. Tokar) spilno zi spetsialistamy inzhenernoplanuval'noho viddilu (nachalnyk-Mukha V. H.) [The planning scheme for the territory of the Transcarpathian region was developed ]. (2011). Kyiv. Retrieved from https://carpathia.gov.ua/sites/default/files/imce/130517_731-i.pdf (accessed 6 April 2020). [in Ukrainian]. 